\title{
Detecção do vírus da laringotraqueíte das galinhas no Brasil ${ }^{1}$
}

\author{
Nilzane Beltrão2 ${ }^{2}$ Thales Quedi Furian², Joice Aparecida Leão ${ }^{3}$, Rosecler Alves \\ Pereira ${ }^{4}$, Lucas Brunelli de Moraes ${ }^{2}$ e Cláudio Wageck Canal ${ }^{2}$
}

\begin{abstract}
Beltrão N., Furian T.Q., Leão J.A., Pereira R.A., Moraes L.B. \& Canal C.W. 2004. [Detection of infectious laryngotracheitis virus in chickens in Brazil.] Detecção do vírus da laringotraqueíte das galinhas no Brasil. Pesquisa Veterinária Brasileira 24(2):85-88. Centro de Diagnóstico e Pesquisa em Patologia Aviária (CDPA), Faculdade de Veterinária, UFRGS, Porto Alegre, RS 91540-000, Brazil. E-mail: nilzaneb@ hotmail.com

A study was carried out in search for evidences of infectious laryngotracheitis virus (ILTV) infections in some Brazilian chicken flocks. Tracheal tissues and swabs were collected from 10 different flocks of layers and broilers displaying respiratory signs of disease. Samples were processes for virus isolation in embryonated eggs and the membranes examined by histopathology. In addition, specimens were examined by polymerase chain reaction (PCR). Three flocks had ILTV positive chickens by virus isolation and PCR. These results confirm the occurrence of ILTV in chickens in Brazil.
\end{abstract}

INDEX TERMS: Infectious laryngotracheitis virus, PCR, virus isolation, avian pathology.

\begin{abstract}
RESUMO.- O propósito deste estudo foi detectar a presença do vírus da laringotraqueíte infecciosa (VLTI) das galinhas em algumas granjas do Brasil. Tecidos da traquéia e suabes foram coletados de 10 lotes de frangos de corte e galinhas de postura com sinais respiratórios. 0 material foi inoculado em ovos embrionados e as membranas corioalantóides examinadas por histopatologia. Além disso, as amostras foram submetidas à reação em cadeia da polimerase (PCR). Três lotes foram positivos para VLTI por isolamento viral e PCR. Os resultados confirmam a presença do VLTI nas galinhas no Brasil.
\end{abstract}

TERM OS DE INDEXAÇÃO: Vírus da laringotraqueíte infecciosa, PCR, isolamento viral, patologia aviária.

\section{INTRODUÇÃO}

0 Vírus da Laringotraqueíte Infecciosa (VLTI) das aves, ou Herpesvírus dos Galídeos tipo 1, é um membro da família Herpesviridae, subfamília Alphaherpesvirinae (Bagust \& Guy 1997; Roizmann 1995). 0 VLTI pode causar uma doença respiratória

\footnotetext{
${ }^{1}$ Recebido em 30 de outubro de 2003.

Aceito para publicação em 26 de março de 2004.

${ }^{2}$ Centro de Diagnóstico e Pesquisa em Patologia Aviária (CDPA), Faculdade de Veterinária da Universidade Federal do Rio Grande do Sul (UFRGS), Porto Alegre, RS 91540-000. E-mail: nilzaneb@ hotmail.com
}

aguda nas aves, caracterizada por dispnéia severa, tosse, expectoração de exsudato muco-sanguinolento e, em casos mais severos, morte em 2 a 3 dias. Taxas de mortalidade de até $70 \%$ têm sido reportadas, embora situem-se geralmente entre 10 e $40 \%$ (Trist et al. 1996, Bagust \& Guy 1997). A forma subaguda da Laringotraqueíte Infecciosa (LTI) caracteriza-se por sinusite, conjuntivite, traqueíte, estertores suaves e baixa mortalidade. A doença tem sido diagnosticada em diversas partes dos Estados Unidos, Europa, Ásia, China e Austrália (Bagust \& Guy 1997). No Brasil, apesar de Hipólito et al. (1974) terem relatado o primeiro isolamento de uma amostra do VLTI a partir de aves com sinais respiratórios e intensa traqueíte hemorrágica, a doença não foi mais descrita no País e é considerada exótica pelo Ministério da Agricultura, Pecuária e Abastecimento (MAPA). Mais recentemente, Vargas (1995) detectou anticorpos contra o VLTI em alguns plantéis avícolas do RS, embora não tenha observado sinais da doença aguda, nem tenham sido efetuadas tentativas de isolar o agente. 0 diagnóstico de LTI é baseado nos sinais clínicos, alterações histológicas e detecção do agente etiológico. Uma variedade de procedimentos diferentes têm sido descritos para a detecção do VLTI, os quais incluem isolamento viral (Hughes \& Jones 1988), imunofluorescência direta (Hitchner et al. 1977, Ide 1978, Wilks \& Kogan 1979, Goodwin et al. 1991), imunoperoxidase (Guy et al. 1992, Abbas \& Andreasen 1996), histopatologia (Pirozok et al. 1957, Bagust \& Guy 1997), técnicas de hibridização de DNA (Abbas et al. 1996) e técnicas da Reação em Cadeia pela Polimerase (PCR) 
(Shirley et al. 1990, Williams et al. 1992). 0 objetivo deste trabalho foi detectar a presença do VLTI no Brasil a partir de galinhas com suspeita clínica da doença.

\section{MATERIAL E MÉTODOS}

\section{Amostras de vírus e materias para exame}

Foram utilizadas como controle positivo as linhagens vacinais Laryngo-vac da Solvay Animal Health (Charles City, IL, EUA), e Cover, da Spafas (Storrs, CT, EUA).

Traquéias hiperêmicas apresentando de leve a moderada hemorragia foram coletadas de 7 lotes de frangos de corte e de 3 lotes de galinhas de postura com sinais respiratórios. Esses lotes, provenientes de diferentes empresas avícolas da Região Sul e Sudeste do Brasil, foram analisados por isolamento viral, PCR e histopatologia.

\section{Isolamento viral}

Aproximadamente 15 traquéias de cada lote foram picadas juntas, maceradas em gral, diluidas a 1:3 (p:v) em solução salina tamponada com fosfatos (PBS) e centrifugadas por 3 minutos a $1200 \times \mathrm{g}$. Ao sobrenadante obtido foram adicionados $200 \mathrm{UI}$ de penicilina, $2,0 \mathrm{mg}$ de sulfato de estreptomicina e $1000 \mathrm{UI}$ de micostatina por $\mathrm{mL}$. Essa suspensão foi inoculado na membrana corioalantóide (MCA) de 5 ovos embrionados livres de patógenos específicos - "Specific Pathogen Free" (SPF) com 9 dias de incubação, na dose de $0,2 \mathrm{~mL} / 0$ vo. Cinco ovos inoculados com PBS foram mantidos como controle negativo, sendo examinados diariamente por ovoscopia. Os embriões mortos nas primeiras 12 horas após a inoculação foram descartados. Após sete dias, os ovos foram abertos e observados quanto à presença de morte embrionária e lesões necrótica s tipo "pock" na MCA, as quais foram analisadas por histopatologia.

Para a comparação da sensibilidade entre a PCR e o isolamento viral, cinco ovos foram inoculados com cada uma das diluições $\left(10^{-1}\right.$ a $\left.10^{-6}\right)$ do controle positivo. As doses infectantes para embriões $\left(E_{I D}\right)$ foram calculadas de acordo com o método de Spearman-Kärber (Villegas \& Purchase 1989).

\section{Reação em Cadeia pela Polimerase (PCR)}

Suabes de traquéia foram ressuspensos em tubos contendo $340 \mathrm{~mL}$ de TE (10 mM Tris. HCl pH 8,0; 1 mM EDTA). O DNA foi preparado pela digestão com proteinase $K$, seguida de extração com fenolclorofórmio (Sambrook et al. 1989). Após precipitação com acetato de sódio e isopropanol, o DNA foi ressuspenso em $50 \mathrm{~mL}$ de TE. Para a PCR, foi utilizado um par de iniciadores (ILTV/PCR 5'e ILTV/PCR 3') selecionados por Abbas et al. (1996), correspondentes a um fragmento do gene da timidina quinase. A PCR foi realizada em um volume final de $25 \mathrm{~mL}$, contendo $50 \mathrm{ng}$ de DNA, $20 \mathrm{pmol}$ de cada iniciador (Invitrogen Corporation, Escócia), 2,5 mM MgCl $10 \mathrm{mM}$ Tris- $\mathrm{HCl} \mathrm{pH}$ 8,5, $50 \mathrm{mM} \mathrm{KCl}, 0,2 \mathrm{mM}$ de cada dNTP e $1 \mathrm{U}$ de Taq DNA Polimerase. 0 tempo, número de ciclos e a temperatura da desnaturação, anelamento e extensão foram como descrito previamente (Abbas et al. 1996). Os controles positivos da reação consistiram de DNA extraído da linhagem vacinal e os controles negativos foram suabes de traquéia de aves SPF, ou tampão TE. A sensibilidade da PCR foi determinada utilizando diluições de $10^{-1}$ a $10^{-6}$ da vacina utilizada como controle positivo e titulada em ovos embrionados.

\section{Histopatologia}

As MCAs contendo lesões necróticas tipo "pock", resultantes da inoculação com material suspeito de VLTI, foram fixadas em formol, processadas em álcool, embebidas em parafina, secionadas a $5 \mathrm{~mm}$ e coradas com hematoxilina e eosina (HE). 0 diagnóstico de LTI foi baseado na visualização de corpúsculos de inclusão intranucleares e na presença de sincícios.

\section{RESULTADOS}

Dos 10 lotes analisados para a presença do VLTI por isolamento viral, em três 33,3\% foram observadas lesões necróticas tipo "pock" na MCA. Lesões necróticas foram observadas em três de cinco MCA do Lote 1, em quatro MCA do Lote 2 e em apenas uma MCA do Lote 3. Na PCR, foram obtidos produtos de amplificação com aproximadamente 647 pares de bases no controle positivo, na linhagem Cover e em amostras dos três lotes positivos no isolamento viral. Destes lotes positivos, 11 das 45 amostras de

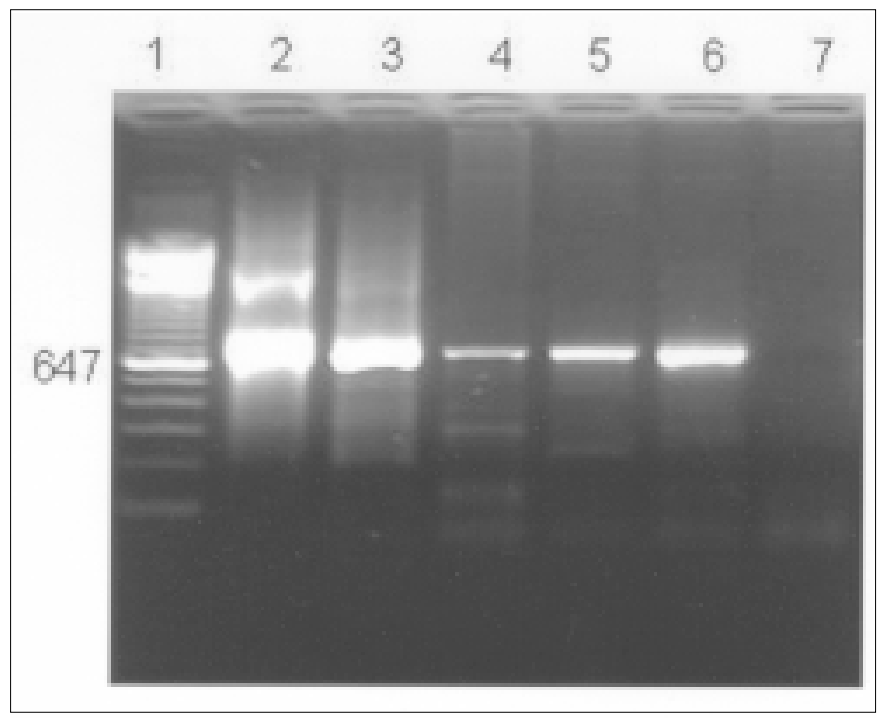

Fig.1. Análise de produtos de PCR de diferentes lotes de aves em gel de agarose $(1,2 \%$ corado com brometo de etídio. Linha 1 : marcador de peso molecular. Linhas 2-7: produtos de amplificação dos seguintes. Linha 2: controle positivo. Linha 3: VLTI, linhagem Cover. Linha 4: amostra lote 1. Linha 5: amostra lote 2. Linha 6: amostra lote 3. Linha 7: controle negativo.

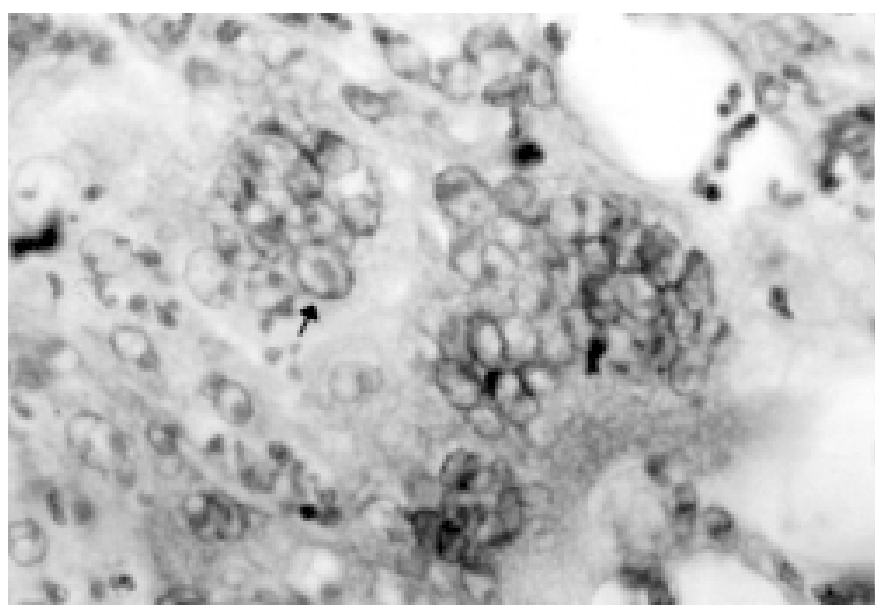

Fig.2. Fotomicrografia de membrana corioalantóide de material do Lote 1 (vide Material e Métodos), de onde foi isolado o VLTI, observando-se um corpúsculo de inclusão intranuclear (seta). HE, obj. 40. 
suabe de traquéia individuais foram positivas (Fig. 1). No Lote 1, três das 15 amostras foram positivas, no Lote 2 , sete amostras foram positivas e, no Lote 3, detectou-se o DNA viral em uma amostra. A sensibilidade da PCR para detecção do DNA do VLTI foi de 6,34 EID $_{50}$.

A análise histopatológica revelou a presença de corpúsculos de inclusão intranucleares e sincícios em duas traquéias oriundas dos Lotes 1 e 2, não tendo sido observadas alterações em nenhuma amostra do Lote 3 . Corpúsculos de inclusão intranucleares foram encontrados em todas as MCAs com lesões examinadas (Fig. 2).

Nos Lotes 4, 5, 6, 7, 8, 9 e 10, não foi detectado VLTI por nenhum dos métodos de diagnóstico utilizados.

\section{DISCUSSÃO E CONCLUSÕES}

Neste trabalho, foram utilizados três métodos (isolamento viral, PCR e histopatologia) para determinar a presença do VLTI em aves domésticas no Brasil. Este vírus somente havia sido isolado e identificado no Brasil em 1974, a partir de um lote de galinhas com sinais respiratórios e intensa traqueíte hemorrágica (Hipólito et al, 1974), não tendo sido mais descrito desde então. A PCR para o diagnóstico de doenças virais é relativamente simples, sensível e específica (Scholz et al. 1994). A PCR aplicada para a detecção do vírus a partir de material clínico teve uma sensibilidade semelhante à inoculação em ovos embrionados. No entanto, a PCR tem a vantagem de ser realizada em menos tempo do que esta última (Scholtz et al. 1994, Alexander \& Nagy 1997).

Através da análise histopatológica, detectou-se corpúsculos de inclusão intranucleares e sincícios diretamente das traquéias de aves clinicamente suspeitas e em todas as membranas que apresentaram lesões necróticas tipo "pock". Apesar do diagnóstico do VLTI baseado na demonstração do corpúsculo de inclusão em tecidos ser considerado menos sensível que o isolamento do VLTI (Guy et al. 1992, Keller \& Hebel 1992, Bagust \& Guy 1997), esses achados histopatológicos são considerados patognomônicos de infecções pelo VLTI (Bagust \& Guy 1997), confirmando a especificidade da PCR. Em muitos casos de doença respiratória, onde se suspeita de VLTI, o diagnóstico preliminar diferencial é feito através da análise histopatológica, antes mesmo da detecção do agente ou do isolamento viral (Humberd et al. 2002). No entanto, os corpúsculos de inclusão são usualmente observados somente no estágio inicial da infecção (Van der Heide 1967).

Nos lotes examinados, não foram observados sinais clínicos da doença aguda, sugerindo que se tratavam de isolados de baixa patogenicidade (William et al . 1992). Dessa forma, torna-se difícil o diagnóstico clínico de LTI em galinhas. Os sinais clínicos observados assemelham-se aos das demais doenças respiratórias de aves, como bronquite infecciosa, influenza aviária, micoplasmose e doença de Newcastle (Soares 1977, Scholz et al. 1994). Muitos autores têm evidenciado níveis baixos intermitentes do vírus na traquéia de aves sem sinais clínicos, realçando o papel da LTI na etiologia da doença respiratória (Hughes et al. 1989, Hughes et al. 1991, Humberd et al. 2002).

Em resumo, com o isolamento viral e o protocolo da PCR estabelecido, juntamente com a análise histopatológica, foi pos- sível verificar que o VLTI está presente em nosso meio atualmente, podendo causar grandes perdas econômicas para os plantéis avícolas do nosso País. A partir dos resultados deste trabalho, medidas para o controle e erradicação desta doença deverão ser implementadas no Brasil, para que sejam diminuídos os prejuízos econômicos advindos da menor produtividade e barreiras sanitárias impostas pelos países importadores.

Agradecimentos.- 0 suporte financeiro foi fornecido pela Fundação de Amparo a Pesquisa do Estado do Rio Grande do Sul (FAPERGS). Nilzane Beltrão, Rosecler Alves Pereira e Lucas Brunelli de Moraes receberam bolsas do Conselho Nacional de Desenvolvimento Científico e Tecnológico (CNPq). Thales Quedi Furian recebeu bolsa BIC/PROPESQ-UFRGS.

\section{REFERÊNCIAS}

Abbas F. \& Andreasen R.J. 1996. Comparison of diagnostic tests for infectious laryngotracheitis. Av. Dis. 40:290-295

Abbas F., Andreasen R.J. \& Jackwood M.W. 1996. Development of a polymerase chain reaction and a nonradioactive DNA probe for infectious laryngotracheitis virus. Av. Dis. 40:56-62.

Alexander H.S. \& Nagy E. 1997. Polymerase chain reaction to detect infectious laryngotracheitis virus in conjunctival swabs from experimentally infected chickens. Av. Dis. 41:646-693.

Bagust, T.J. \& Guy J.S. 1997. Laryngotracheitis, p.527-539. In: Calnek B.W., Barnes H.J., Beard C.W., Mcdougald L.R.\& Saif Y.M. (ed.) Diseases of Poultry. 10th ed. lowa State University Press, Ames.

Goodwin M.A., Smeltzer M.A., Brown J., Resurreccion R.S. \& Dickson T.G. 1991. Comparison of histopathology to the direct immunofluorescent antibody test for the diagnosis of infectious laryngotracheitis in chickens. Av. Dis. 35:389-391.

Guy J.S., Barnes H.J. \& Smith L.G. 1992. Rapid diagnosis of infectious laryngotracheitis using a monoclonal antibody-based immunoperoxidade procedure. Avian Pathol.. 21:77-86.

Hipólito O., Soares L.A., Pereira O.A.C., Pinto A.A. \& Bottino, J.A. 1974 Isolamento e identificação do vírus da laringotraqueíte infecciosa das galinhas no Brasil, p.16. In: Congresso Brasileiro de Microbiologia, Rio de Janeiro. (Resumo)

Hitchner S.B., Fabricant J. \& Bagust J. 1977. A fluorescent-antibody study of the pathogenesis of infectious laryngotracheitis. Avian Dis. 21:185194.

Hughes C.S. \& Jones R.C. 1988. Comparison of cultural methods for primary isolation of infectious laryngotracheitis virus from field materials. Avian Pathol. 17:295-303.

Hughes C.S., Gaskell R.M., Jones R.C., Bradbury J.M. \& Jordan F.T. 1989. Effects of certain stress factors on the re-excretion of infectious laryngotracheitis virus from latently infected carrier birds. Res. Vet. Sci. 46:274-276.

Hughes C.S., Williams R.A, Gaskell R.M., Jordan F.T, Bradbury J.M., Bennet M. \& Jones R.C. 1991. Latency and reactivation of infectious laryngotracheitis vaccine virus. Arch. Virol. 121:213-218.

Humberd J., Garcia M., Riblet S.M., Resurreccion R.S. \& Brown T.P. 2002. Detection of infectious laryngotracheitis virus in formalin-fixed, paraffinembedded tissues by nested polymerase chain reaction. Avian Dis. 46:6474.

Ide P.R. 1978. Sensitivity and specificity of the fluorescent antibody technique for detection of infectious laryngotracheitis virus. Can. J. Comp. Med. 42:54-62.

Keeler C.L., Kingsley D.H. \& Adams Burton C.R. 1991. Identification of the thymidine kinase gene of infectious laryngotracheitis virus. Avian Dis. 35:920-929.

Pirozok R.P., Helmbolt C.F. \& Jungher E.L. 1957. A rapid histological technique for the diagnosis of infectious avian laryngotracheitis. J. Am. Vet. Med. Assoc. 103:406-407. 
Roizmann B. 1995. The family Herpesviridae, p.2221-2230. In: Fields B.N., Knite D.M., Howley P.M. Fields Virology. 3rd ed. Lippincott-Raven Publisher, Filadélfia, USA.

Sambrook J., Fritsch E.F.E. \& Maniatis T. 1989. Molecular Cloning: A Laboratory Manual. 2nd ed. Cold Spring Harbour Laboratory Press, Cold Spring Harbor, New York.

Shirley M.W., Kemp D.J., Sheppard D M. \& Fahey K.L. 1990. Detection of DNA from infectious laryngotracheitis virus by colorimetric analyses of polymerase chain reaction. J. Virol. Meth. 30:251-260.

Sholz E., Porter R.E. \& Guo P. 1994. Differential diagnosis of infectious laryngotracheitis from other avian respiratory disease by a simplified PCR procedure. J. Virol. Meth. 50:313-322.

Soares L.A. 1977. Caracterização da amostra LT-1543 do vírus da laringotraqueíte infecciosa das galinhas. Tese de Doutorado, Escola Paulista de Medicina, São Paulo. 61p.

Trist H.M., Tyack S.G., Johnson M.A, Prideaux C.T. \& Sheppard M. 1996. Comparison of the genomic short regions of a vaccine strain (AS-2) and a virulent strain (CSW-1) of infectious laryngotracheitis virus (gallid herpesvirus 1). Avian Dis. 40:130-139.

Vargas R.E.S. 1995. Laringotraqueíte infecciosa das aves: Estudo epidemiológico em plantéis avícolas no Estado do Rio Grande do Sul. Tese de Mestrado, Universidade Federal Rio Grande do Sul, Porto Alegre, Rio Grande do Sul. 106p.

Villegas P. \& Purchase H.G. 1989. Titration of biological suspensions, p.186-191. In: Purchase H.G., Arp L.H., Domermuth C.H. \& Pearson J.E. (ed.) A Laboratory Manual for the Isolation and Identification of Avian Pathogens, 3rd ed. American Association of Avian Pathologists, Kennett Square, PA, USA.

Wilks C.R. \& Kogan V.G. 1979. An immunofluorescence diagnostic test for avian infectious laryngotracheitis. Aust. Vet. J. 55:385-388.

Williams R.A., Bennet M., Bradbury J.M., Gaskell R.M., Jones R.C. \& Jordan, F.T.W. 1992. Demonstration of sites of latency of infectious laryngotracheitis virus using the polymerase chain reaction. J. Gen. Virol. 73:2415-2420. 